\title{
Improvement of the technological process of carbonated spring water by implementing the quality and food safety management standards
}

\author{
Maria Popa ${ }^{1}$, Ioana Glevitzky ${ }^{2, *}$, and Adina Sârb $^{2}$ \\ ${ }^{1}$ Faculty of Economic Sciences, "1 Decembrie 1918” University of Alba Iulia, Romania \\ ${ }^{2}$ Doctoral School, Faculty of Engineering, "Lucian Blaga" University of Sibiu, Romania
}

\begin{abstract}
Bottled spring water must be health providing, clean, without microorganisms, parasites or substances. The design, manufacturing and management of processes, related to spring water bottling involves controlling the safety issues that may arise in the production processes. These aspects are not sufficient to prevent hazards and they must be related to the implementation of a quality and food safety systems. The aim of the paper is to improve the technological process of carbonated spring water in Monopolis S.A Company, by implementing the quality and food safety management standards. The methodology is based on the implementation requirements of the HACCP principles, included in ISO 22000 standard. On the other hand, the results of the work highlight the safety parameters of "Roua Apusenilor"carbonated spring water: physico - chemical, purity and microbiological. A HACCP generic model was developed for this company. In this case study, the hazard analysis and risk assessment was implemented with the identification of the critical control points, which includes filtration and impregnation of carbon dioxide. At the same time, the loss of carbon dioxide content in PET bottles of 2 and 2.5 litres during the shelf life period was observed and a statistical analysis of the resulting experimental data was performed. There is a significant decrease of carbon dioxide content in the two packaging volumes of about 3.2 and $4.6 \mathrm{~g} / 1$ at the end of the best before period.
\end{abstract}

\section{Introduction}

Drinking water must be health providing, clean, without microorganisms, parasites or substances, which, by number or concentration, can be a potential hazard for human and animal health [1,2]. However, water in nature is never pure; given the interactions with the environment, it contains gases, mineral and organic substances, dissolved in suspension [3]. Water pollution that comes from industry, agriculture or households, returns negatively back to the environment $[4,5]$.

Groundwater resources from alpine and mountainous karst aquifers play an important role for public water supply in many areas throughout the world [6]. The quality control of

* Corresponding author: ioana.glevitzky@yahoo.com 
natural spring water is of interest and is a priority action of government authorities. Raw water plays an essential role for drinking purposes and for other sanitary uses and industrial processes [7]. A decrease in the number of springs or the drop in their discharge, as well as disadvantageous changes in chemistry and quality of spring waters, indicate degradation of the environment [8].

In bottling process, carbonation is considered as the impregnation of a liquid with $\mathrm{CO}_{2}$ gas, which, in part, forms carbonic acid when dissolving in water. This acid is instable. In practice, $\mathrm{CO}_{2}$ is the only gas suitable for producing the "sparkle" in water. The solubility is of such a nature that it allows retention in solution at ambient temperature and also allows the release of an attractive swirl of bubbles from the body of the drink when slightly agitated. The gas is also inert, non-toxic and virtually tasteless, and is available in liquefied form at moderate cost [9].

The necessity of storing carbonated water in more practical and lighter bottles has led to the replacement of the more traditional glass with the new polyethylene terephthalate (PET) bottles. These bottles require a higher carbonation in order to compensate the $\mathrm{CO}_{2}$ losses through the PET walls $(60 \%)$ during the storage and at every open of the cap $(30 \%)$ [10, $11]$.

The present paper seeks ways of testing the quality of drinking bottled spring water, respectively to improve the bottling process of carbonated spring water through the implementation of the management system for quality and food safety requirements according to ISO 22000 standard. The study results show the values of physico-chemical and microbiological parameters for "Roua Apusenilor" sparkling water. The work aims also to monitor the carbon dioxide content of "Lucia" spring water in time and to establish its loss in a 2 litre as well as a 2.5 litre PET receipient.

\section{The analysis of Roua Apusenilor carbonated spring water}

In order to investigate the water quality of carbonated spring Roua Apusenilor, the physicochemical indicators, the purity of the water origin, as well as the constituents naturally present in the spring water were determined according to G.O. no.1020/2005 [12].

Table 1. Results of the physical-chemical analysis for Roua Apusenilor sparkling water.

\begin{tabular}{|c|c|c|c|c|}
\hline No. & Parameter & M.U. & $\begin{array}{c}\text { Determined } \\
\text { value }\end{array}$ & $\begin{array}{c}\text { Maximum allowed values according to GO } \\
\mathbf{1 0 2 0} / \mathbf{2 0 0 5}\end{array}$ \\
\hline 1 & Temperature & ${ }^{\circ} \mathrm{C}$ & 21.2 & According to the natural state of water \\
\hline 2 & $\mathrm{pH}$ & $\begin{array}{c}\mathrm{pH} \\
\text { units }\end{array}$ & 5.2 & According to the natural state of water \\
\hline 3 & Conductivity & $\mu \mathrm{S} / \mathrm{cm}$ & 386 & According to water mineralization \\
\hline 4 & Chlorides & $\mathrm{mg} / 1$ & 4.41 & According to the specific characteristics of water \\
\hline 5 & Sulfates & $\mathrm{mg} / 1$ & 16.86 & According to the specific characteristics of water \\
\hline 6 & Bicarbonats & $\mathrm{mg} / 1$ & 237.9 & According to the specific characteristics of water \\
\hline 7 & Calcium & $\mathrm{mg} / 1$ & 73.3 & According to the specific characteristics of water \\
\hline 8 & Magnezium & $\mathrm{mg} / 1$ & 1.90 & According to the specific characteristics of water \\
\hline 9 & Sodium & $\mathrm{mg} / 1$ & 1.69 & According to the specific characteristics of water \\
\hline 10 & Potasium & $\mathrm{mg} / 1$ & 1.18 & According to the specific characteristics of water \\
\hline 11 & Iron total & $\mathrm{mg} / 1$ & 0.018 & According to the natural state of water \\
\hline 12 & Dry residue & $\mathrm{mg} / 1$ & 24 & According to the specific characteristics of water \\
\hline 13 & $\begin{array}{c}\text { Disssolved } \\
\text { Oxygen }\end{array}$ & $\mathrm{mgO} / 1$ & 1.51 & According to the specific characteristics of water \\
\hline 14 & Carbon dioxide & $\mathrm{mg} / 1$ & 5368 & According to the specific characteristics of water \\
\hline 15 & Hydrogen sulfide & $\mathrm{mg} / 1$ & $<0.01$ & According to the natural state of water \\
\hline
\end{tabular}


In tables no. 1 and 2 the physico-chemical results of the sample Roua Apusenilor carbonated spring water are presented; source Lucia Cave, from the village of Sohodol, Alba County.

Table 2. The results of the purity indicators for Roua Apusenilor sparkling water.

\begin{tabular}{|c|c|c|c|c|}
\hline No. & Parameter & M.U. & $\begin{array}{l}\text { Determined } \\
\text { value }\end{array}$ & $\begin{array}{l}\text { Maximum allowed values } \\
\text { according to GO } 1020 / 2005\end{array}$ \\
\hline 16 & Ammonium & $\mathrm{mg} / \mathrm{l}$ & $<0.005$ & 0.5 \\
\hline 17 & CCO-Mn & $\mathrm{mgO}_{2} / 1$ & 1.12 & 3 \\
\hline 18 & Zinc & $\mathrm{mg} / \mathrm{l}$ & 0.019 & 5 \\
\hline 19 & Phenols & $\mu \mathrm{g} / 1$ & $<0.5$ & 0.5 \\
\hline 20 & Surfactants & $\mathrm{mg} / \mathrm{l}$ & $<0.1$ & 0.2 \\
\hline 21 & $\begin{array}{c}\text { Polycyclic aromatic } \\
\text { hydrocarbons }\end{array}$ & $\mu \mathrm{g} / 1$ & $<0.00018$ & 0.1 \\
\hline 22 & $\begin{array}{l}\text { Tetrachloroethane and } \\
\text { trichloroethane }\end{array}$ & $\mu \mathrm{g} / 1$ & $<0.05$ & 10 \\
\hline 23 & Trihalometans & $\mu \mathrm{g} / 1$ & $<0.15$ & 100 \\
\hline 24 & $\begin{array}{c}\text { Pesticides } \\
\text { - on each component } \\
\text {-the sum of all components } \\
\text { in each class }\end{array}$ & $\begin{array}{l}\mu \mathrm{g} / 1 \\
\mu \mathrm{g} / 1\end{array}$ & $\begin{array}{l}<0.008 \\
<0.008\end{array}$ & $\begin{array}{l}0.5 \\
0.1 \\
\end{array}$ \\
\hline
\end{tabular}

Tables no. 1 and 2 show that the values of the parameters are within the established limits according to the national laws related to spring waters. The quality of Roua Apusenilor sparkling water, having as its source Lucia Cave from Sohodol village, is conforming.

\section{Risk analysis for the bottling process of carbonated spring water "Roua Apusenilor"}

The implementation of a quality and food safety management system according to ISO 22000 [13] can provide control over the technological process, in all stages, through evaluation of three possible risks: physical, chemical and biological. In this sense, a generic Hazard Analysis Critical Control Point (HACCP) model was developed.

According to article 5(1) of Regulation (EC) No. 852/2004 on the hygiene of foodstuff [14] requires that all food business operators implement and maintain a procedure based on the HACCP principles. However, there are a number of external pressures (requirements of the large chain stores, high competition, product visibility on the market, etc.), which lead to the implementation and certification of quality systems and food safety. The reasons for this decision are generally of an internal nature. In the food industry, at global level there is an increasing growth of certifications based on ISO 22000 (Food safety management systems), although the implementation and certification of the standard is currently optional [15].

The Hazard Analysis Critical Control Points system (HACCP) is a food safety management system that uses the approach of identification, evaluation, and controlling critical points in food and drink production, and the framework of its concept consists of 7 principles [16]: 1: Conduct a hazard analysis; 2: Determine the critical control points (CCPs); 3: Establish critical limits; 4: Establish monitoring procedures; 5: Establish corrective actions; 6: Establish verification procedures; 7: Establish record-keeping and documentation procedures. 
According to ISO 22000 standard, following the analysis and the evaluation of the hazards that can appear during all the technological stages of the "Roua Apusenilor" sparkling water bottling (figure 1).

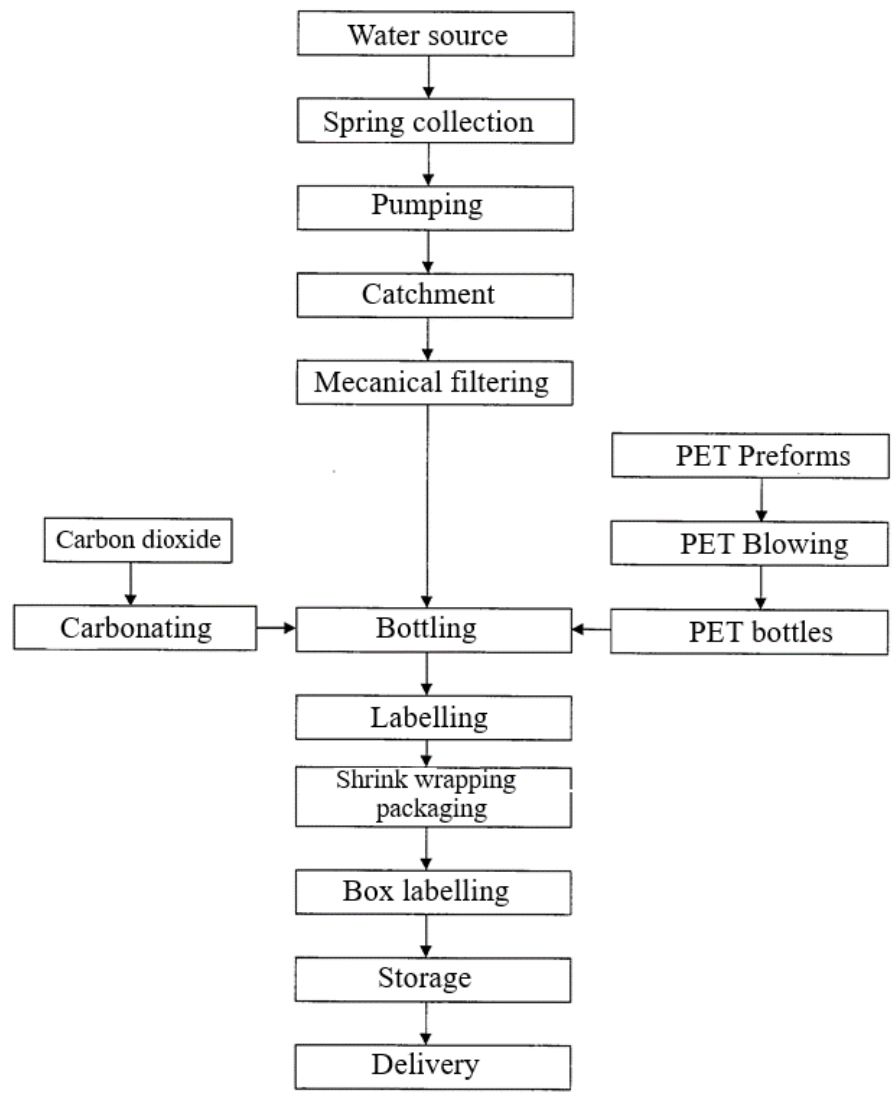

Fig. 1. Process flow diagram of carbonated water production and bottling

The risk assessment aims to determine for each safety food hazard whether elimination or reduction to the acceptable level leads to the production of safety food and if it is necessary to control the production in order to keep it within acceptable levels.

The probability of occurrence (frequency) of each identified hazard and their gravity (severity) is analysed, considering that the control measures (or preventive ones) have not achieved their purpose.

The gravity $(\mathrm{G})$ represents the consequences suffered by a consumer because of exposure to a contaminant and it is classified into three levels:

- High: fatal consequences, serious illnesses, incurable damages), that occur immediately or after a longer period.

- Medium: Substantial damages and / or illnesses

- Small: minor injuries and / or diseases, lack of effects or minor effects or consequences that occur only after exposure to high doses, long periods.

Probability of occurrence $(\mathrm{P})$ is the probability of having a contaminant due to the lack of control of food protection in the final product at the time of consumption. Probability is determined by measurements or observations during certain specific situations occurring within the company. It is classified into 3 frequency levels: 
- Small: practically impossible to produce or improbable ("theoretical risk").

- Medium: can occur, it happens to occur.

- High: it appears systematically, repeatedly.

Depending on gravity and probability of occurrence, the risk class (RC) is established using the table 3 [17]:

Table 3. Establish the risk class (RC).

\begin{tabular}{|c|c|c|c|}
\hline Gravity (G) & \multicolumn{3}{|c|}{$\begin{array}{l}\text { Probability of occurrence (P) } \\
\text { (in the final product; at consumption) }\end{array}$} \\
\hline High & 3 & 4 & 4 \\
\hline Medium & 2 & 3 & 4 \\
\hline Small & 1 & 2 & 3 \\
\hline & Small & Medium & High \\
\hline
\end{tabular}

The HACCP system approaches the hygienic quality of the food products, being the most efficient means of guaranteeing and controlling the security of the food products. All types of potential hazards (biological, chemical, physical) that appear in a natural way in the bottled water, either because of the exposure or the contact with a certain environment, or as an effect of a deficiency of the production process are taken into account.

Table 4. The analysis and evaluation of the hazards corresponding to the established CCPs for carbonated water.

\begin{tabular}{|c|c|c|c|c|c|c|c|c|c|c|}
\hline Stage & $\begin{array}{l}\text { Type of } \\
\text { hazard }\end{array}$ & Hazard description & ${ }^{1} \mathbf{G}$ & ${ }^{2} \mathbf{P}$ & $\mathbf{R C}$ & $\mathbf{Q}_{1}$ & $\mathbf{Q}_{2}$ & $\mathbf{Q}_{3}$ & $\mathbf{Q}_{4}$ & $\mathrm{CCP}$ \\
\hline 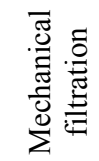 & Physical & $\begin{array}{l}\text { Impurities (sand, } \\
\text { sediment, sludge, rust } \\
\text { or particles in } \\
\text { suspension) }\end{array}$ & Low & High & 3 & yes & yes & - & - & $\mathrm{CCP} 1$ \\
\hline 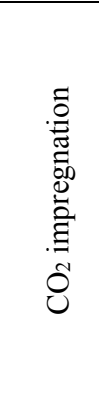 & Biological & $\begin{array}{l}\text { Pathogens (E.coli, } \\
\text { Clostridium spp, } L . \\
\text { monocytogenes, } \\
\text { Salmonella spp, } \\
\text { Staphyloccocus spp, } \\
\text { Y. enterocolitica, C. } \\
\text { jejuni, P. aeruginosa, } \\
\text { Shigella } \text { spp, } \\
\text { Streptococcus } \\
\text { faecalis, Legionella } \\
\text { spp, etc), parasites }\end{array}$ & High & Low & 3 & yes & yes & - & - & $\mathrm{CCP} 2$ \\
\hline
\end{tabular}

${ }^{1} \mathrm{G}$ - Gravity; ${ }^{2} \mathrm{P}$ - Probability of occurrence; $\mathrm{Q}_{1-4}-$ Question 1-4.

The risk assessment that can appear throughout all phases of spring water bottling process (figure 1) leads to the idea for inclusion of the mechanical filtration of the spring water and the carbon dioxide impregnation as a CCPs - critical control points.

Where $\mathrm{Q}_{1}, \mathrm{Q}_{2}, \mathrm{Q}_{3}, \mathrm{Q}_{4}$ are the four next questions from the decision tree [18-19]: 1. Do control preventative measure(s) exist? 2. Is the step specifically designed to eliminate or reduce the likely occurrence of a hazard to an acceptable level? 3. Could contamination with identified hazard(s) occur in excess of acceptable level(s) or could this increase to unacceptable levels? 4. Will a subsequent step eliminate identified hazard(s) or reduce likely occurrence to an acceptable level? 
Table 5. Critical limits, monitoring procedures, corrective actions and documents for each CCPs.

\begin{tabular}{|c|c|c|c|c|c|c|c|}
\hline Stage & $\begin{array}{l}\text { CCP } \\
\text { (no.) }\end{array}$ & $\begin{array}{c}\text { Control } \\
\text { measures }\end{array}$ & $\begin{array}{l}\text { Critical } \\
\text { limits }\end{array}$ & Monitoring & $\begin{array}{l}\text { Corrective } \\
\text { actions } \\
\text { and } \\
\text { measures }\end{array}$ & $\begin{array}{l}\text { Records, } \\
\text { Documents }\end{array}$ & $\begin{array}{l}\text { Responsibi- } \\
\text { lities }\end{array}$ \\
\hline 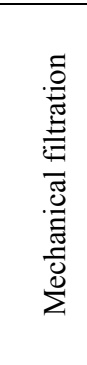 & CCP1 & $\begin{array}{c}\text {-Pressure } \\
\text { difference } \\
\text { monitoring, } \\
\Delta \mathrm{p} \text { on filter } \\
\text { plate, } \\
\text { - Pressure } \\
\text { manometer } \\
\text { calibration. }\end{array}$ & $\begin{array}{l}\text { Maximum } \\
4 \text { bars }\end{array}$ & At 1 hour & $\begin{array}{c}\text { - Change } \\
\text { filters } \\
\text { cartons, } \\
\text { - Washing } \\
\text { filters, } \\
\text { - Filter } \\
\text { plate } \\
\text { inspection, } \\
\text { - Personal } \\
\text { training. }\end{array}$ & $\begin{array}{c}- \\
\text { Operational } \\
\text { control } \\
\text { sheet, } \\
\text { - Input } \\
\text { water } \\
\text { quality } \\
\text { monitoring } \\
\text { register. }\end{array}$ & $\begin{array}{c}\text {-Operator } \\
\text {-Quality } \\
\text { department } \\
- \\
\text { Maintenance } \\
\text { manager }\end{array}$ \\
\hline 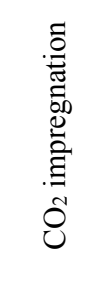 & $\mathrm{CCP} 2$ & $\begin{array}{c}-\mathrm{CO}_{2} \\
\text { content } \\
\text { analysis } \\
\text { in product }\end{array}$ & $\begin{array}{c}\text { Minimum } \\
2500 \mathrm{mg} / \mathrm{l} \\
\mathrm{CO}_{2}\end{array}$ & Each lot & $\begin{array}{c}\text { - Replace } \\
\mathrm{CO}_{2} \text { tank, } \\
\text { - } \mathrm{CO}_{2} \text { air } \\
\text { flow } \\
\text { regulation } \\
\text { - Operator } \\
\text { training. }\end{array}$ & $\begin{array}{l}\text { Operational } \\
\text { control } \\
\text { sheet, } \\
\text {-Quality of } \\
\text { final } \\
\text { product } \\
\text { monitoring } \\
\text { register }\end{array}$ & $\begin{array}{c}\text {-Operator } \\
\text {-Quality } \\
\text { department } \\
- \\
\text { Maintenance } \\
\text { manager }\end{array}$ \\
\hline
\end{tabular}

The implementation of an efficient management system for the security of the food products (ISO 22000) ensures the optimal conditions of monitoring and controlling within the water processing and at the same time preventing the risk of its contamination. The HACCP principles were applied and the identified critical control points include filtration and ozone water treatment. Also, for each CCPs critical limits, monitoring procedures, corrective actions and records that provide evidence of actions were established.

\section{The variation of carbon dioxide in "Roua Apusenilor" carbonated spring water}

Standard PET bottles, made only from polyethylene terephthalate granules, do not meet the stringent conditions required to store carbonated beverages. Thus, penetration of oxygen through the walls of the standard PET bottle, respectively, the diffusion of carbon dioxide is sufficient to alter the sensory characteristics as well as the loss of a large amount of carbon dioxide.

Standard PET bottles do not provide sufficient protection against oxygen penetration, thus, for PET permeability to oxygen and carbon dioxide, PET bottle manufacturers need to conduct advanced studies and use "barrier materials".

\subsection{The loss of carbon dioxide from sparkling water stored in PET bottles}

The experimental results of the study cover the period between 0 and 350 days. The laboratory research analysed the carbon dioxide content in time, comparing the carbonated water samples, bottled in 2 and 2,5 litre PET bottles. The samples were carbonated spring water "Roua Apusenilor", made the same day under the same conditions. The $\mathrm{CO}_{2}$ level has 
been verified approximately every 2-3 weeks. The purpose of this study is to identify the sample in which the $\mathrm{CO}_{2}$ is better preserved and dosed.

A special device was used to verify the $\mathrm{CO}_{2}$ pressure inside the sealed bottles. This device is made up of a body, a mobile part, a rubber ring, a piercing needle, a manometer and a sealing mechanism.

The device's body is fixed on the superior part of the bottle, vertically, allowing the rubber ring and the needle to rest upon the bottle's cap. Pressing the sealing mechanism, the needle penetrates the cap up to the space above the liquid. Through this way, the manometer indicates the $\mathrm{CO}_{2}$ pressure from this space. Using a correlation table, the $\mathrm{CO}_{2}$ beverage content can be measured $\left(\mathrm{g} \mathrm{CO}_{2} /\right.$ litre) as a function of the manometer reading and the temperature of the sample [20].

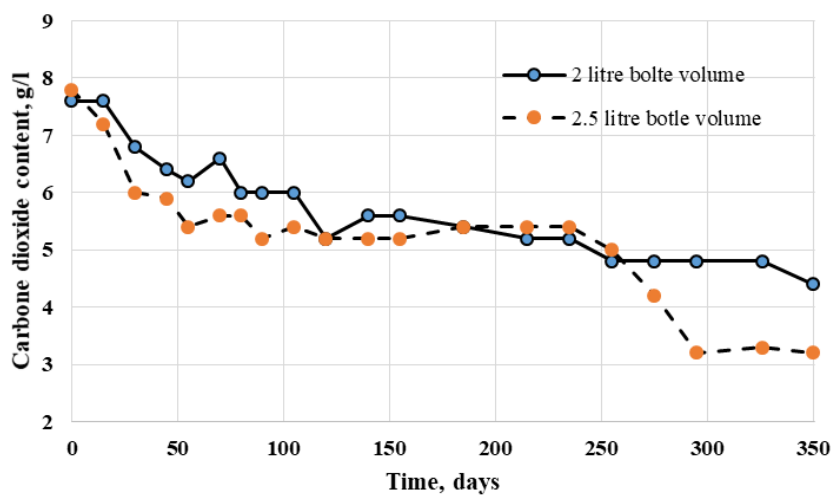

Fig. 2. Time variation of carbon dioxide content in PET bottles.

The results from the first and last day of the experiment were very important for this study. The PET bottles of 2 and 2.5 litre had at the beginning 7.6, respectively $7.8 \mathrm{~g} / 1 \mathrm{CO}_{2}$ content. After approximately a year, the values were of 4.4 , respectively $3.28 \mathrm{~g} / \mathrm{C} \mathrm{CO}_{2}$ content. So, PET bottles of 2.5 litre requires a supplementary dosage because of its large volume.

\subsection{Statistical analysis of carbon dioxide variation in time}

A comparison regarding $\mathrm{CO}_{2}$ content loss in the two types of polyethylene terephthalate (PET) according to their volumes, in which the company bottles the carbonated spring water, mathematical statistic was used. Through $\mathrm{F}$ test of Fischer-Snedecor, dispersions of the two series of experiments were compared. The values found were $\mathrm{s}_{1}{ }^{2}=-2.2881$ for the carbonated spring water bottled in 2 litres bottles and $\mathrm{s}_{2}{ }^{2}=-3.5676$ for the carbonated spring water bottled in 2.5 litres. By choosing the threshold of significance equal to 0.1 we had $\alpha / 2=0.05$, with degrees of freedom $v_{1}=v_{2}=19$.

Because $-2.2881>-3.5676$, from the calculation results (1):

$$
F=\frac{s_{1}^{2}}{s_{2}^{2}}=\frac{-2.2881}{-3.5676}=0.6413
$$

According to critical values $[21]$ of $F$ distribution $F_{0.05}(19,19)=2.17$. Since this value is greater than $F=0.6413$ found experimentally, we can admit that the variation in carbon dioxide in the two different volume packages does not differ significantly. 


\section{Conclusion}

The study constitutes an investigation regarding the quality of the "Roua Apusenilor" sparkling water and justifies the importance of the proper processing in all the technological stages of bottling in order to obtain a product without risks. The implementation of an efficient management system for the security of the food products ensures the optimal conditions of monitoring and control within the water processing and at the same time preventing the risk of contamination.

The results obtained for parameters of "Roua Apusenilor" sparkling water fall within the values allowed by the legislation Also, a HACCP generic model, included in ISO 22000:2018 standard, was developed for this process. In this case study, the analysis and assessment of hazards that may occur during processing was implemented for sparkling water bottling stages, respectively an identification of the critical control points, which includes filtration and impregnation of carbon dioxide. The HACCP principles, were applied in order to improve the food safety and security, to reduce the risks resulted from the consumption of "Roua Apusenilor" sparkling spring water.

The total carbon dioxide content loss over the year is relatively high under normal storage conditions. Basically, for standard PET bottles, the amount of $\mathrm{CO}_{2}$ originally introduced is halved. However, the statistical analysis shows that the loss of carbon dioxide in packages of different volumes does not differ significantly.

\section{References}

1. M. Decun, Igiena animalelor şi a mediului, Mirton, 73 (2007)

2. S. Bungau, C. Bungau, D. M. Tit, Studies about last stage of product lifecycle management for a pharmaceutical product, J Environ Prot Ecol, 16 (1), (2015)

3. A. Todoran, M. Glevitzky, JAP\&T, 15 (4), 515 (2009)

4. S.A. Alrumman, A.F. El-kott, S.M.A.S. Keshk, Am J Environ Engineer, 3, 88 (2016)

5. M. Popa, M. Glevitzky, D. Popa, S. Varvara, G.-A. Dumitrel, Study on Soil Pollution with Heavy Metals Near the River Ampoi, Alba County, J Environ Prot Ecol, 13 (4), 2123-2129, (2012)

6. A.H. Farnleitner, I. Wilhartitz, G. Ryzinska, A.K.T. Kirschner, H. Stadler, M.M. Burtscher, R. Hornek, U. Szewzyk, G. Herndl, R.L. Mach, Environ. Microbiol., 7 (8), 1248 (2005)

7. F. Winquist, J. Olsson, M. Eriksson, Anal. Chim. Acta, 683, 192 (2011)

8. A. Michalik, Pol. J. Environ. Stud., 17 (3), 357 (2008)

9. A.H. Varnam, J.P. Sutherland, Food Products Series. Technology, chemistry and microbiology, 2, 146 Aspen (1999)

10. M. Glevitzky, A.G. Brusturean, D. Perju, G. Laslău, L. Matyas, Chem. Bull "Politehnica" Univ. Timisoara, 50 (64), 18 (2005)

11. M. Glevitzky, A.G. Brusturean, D. Dumitrel, D. Perju, Analele Universităţii „Eftimie Murgu” Reşiţa, 1 (1) XII, 138 (2005)

12. Hotărârea nr. 1020 pentru aprobarea Normelor tehnice de exploatare și comercializare a apelor minerale natural, (2005)

13. ISO 22000 Food safety management systems - Requirements for any organization in the food chain, International Organization for Standardization: Geneva, Switzerland (2018)

14. Regulation (EC) No. 852 of the European Parliament and of the Council of 29 April 2004 on the hygiene of foodstuffs. OJ L 139, 1 (2004)

15. I. Maiorescu, , Amfiteatru Econ, 10 (2), 126 (2008)

16. I. Damikoukaa, A. Katsirib, C. Tziac, Desalination 210, 138 (2007)

17. *** National Good Practice Guide for Food Safety - HACCP Food Safety System, Uranus, 122 (2007)

18. N.G. Marriott, R.B. Gravani, Principles of food sanitation, Springer, 170 (2005)

19. R.H. Schmidt, G.E. Rodrick, Food safety handbook, John Wiley\&Sons, 276 (2003) 
20. SR 2567-2, N 85, ASRO, Băuturi răcoritoare. Metode de analiză- Determinarea dioxidului de carbon (1999)

21. Electronic Statistics Textbook, Tulsa, OK: StatSoft, Inc. (2011) 